\title{
Order-picking in deep cold - physiological responses of younger and older females. Part 1: heart rate
}

\author{
Karsten Kluth*'Sandra Baldus and Helmut Strasser \\ Ergonomics Division, University of Siegen, Paul-Bonatz-Str. 9-11, D-57068 Siegen, Germany
}

\begin{abstract}
The sales figures of chilled and frozen food have been rising steadily over the years. Naturally, this has also led to an increase in the number of jobs related to these goods. While these workplaces are becoming more and more important there are, nevertheless, only a few investigations into the effects of working in deep cold on humans. Order-picking in a cold environment represents a high workload. Especially working at $-24^{\circ} \mathrm{C}$ with wearing heavy cold protective clothing leads to explicitly higher strain. Since performance decreases with age, varying physical strain between younger and older employees can hypothetically be expected. In order to quantify the physiological responses to working in the cold, 15 subjects of two female age groups, each, (20- to 35-year-olds and 40- to 65-year-olds) were asked to carry out whole working day tasks in a chill room $\left(+3^{\circ}\right)$ and in a cold store $\left(-24^{\circ} \mathrm{C}\right)$. Simultaneously, heart rate and other physiological relevant parameters were measured.
\end{abstract}

Keywords: Field Study, Severe Environmental Conditions, Age-adjusted Strain

\section{Introduction}

In recent years, the food market has undergone a major change, i.e. a shift away from fresh and homegrown foods towards chilled and frozen foods. As shown in Figure 1, this trend was also reflected by growing consumption and sales figures of frozen food. This is also associated with a growing number of workplaces related to this market, whereby an upward trend may be expected. Manual order-picking, e.g., poses a high physical stress and strain on the workers. Due to its "heating effect" this physical strenuous work must be seen as beneficial and necessary rather than disadvantageous when working in a cold store with temperatures of approximately $-24^{\circ} \mathrm{C}$ (cp. $[14,15])$. Nevertheless, working in a cold environment may be a significant health risk factor (cp. $[8,25])$, even when wearing adequate cold protective clothing. When trying to optimize the working conditions in cold-storage depots, a number of scientific studies (cp. $[14,15,18,23]$ ) elaborated that improvements should focus on cold-protective clothing as well as duration and frequency of warming-up breaks. Work organisation as well as technical and constructional equipment in cold-storage depots should also be designed on the basis of ergonomic measurements. However, this is feasible only to a minor extent due to management requirements and operational equipment. As already mentioned, an inadequate protection against cold may have an impact on individual's health, whereby increased muscular strain and different musculoskeletal complaints and symptoms can be the outcome (cp. [17,22]). According to Mäkinen [16] and Hassi et al. [9], chronic health problems as a consequence of everyday cold exposures cannot be avoided completely. These specifically include cardiovascular diseases, respiratory symptoms, musculoskeletal disorders, peripheral circulation problems and negative skin sensations. According to Boothby et al. [3], the physical capacity and the energy metabolism decreases with an advanced age. Therefore, it must be assumed that the ability of protection against cold inevitably decreases with an advanced age.

*Corresponding author. E-mail: kluth@ergonomie.uni-siegen.de 
Laboratory studies carried out in the past (cp. [1,4$7,10,13])$ investigated the physiological responses to working in deep cold. But laboratory studies even when focusing on the effects on the human organism not always comply with real tasks [26]. Therefore, Penzkofer et al. (cp. [20-21]) executed whole working day tests with 15 male subjects (Ss) of two age groups, each, under real working conditions, whereby, e.g., heart rate values of 30 beats per minute (bpm) and more above the resting level were measured for all Ss when working in the cold store. These values indicated a physical strain of the Ss which, at least, at distinct times, exceeded the endurance level. The heart rate values showed only moderate differences between the two age groups, which can be attributed to similar physical capacities, carried out by a standard $\mathrm{PWC}_{130}$ test. In the light of the results of Penzkofer et al., it can be assumed that (due to their lower physical capacity) the physiological responses of females will be higher when working in the coldstorage depot.
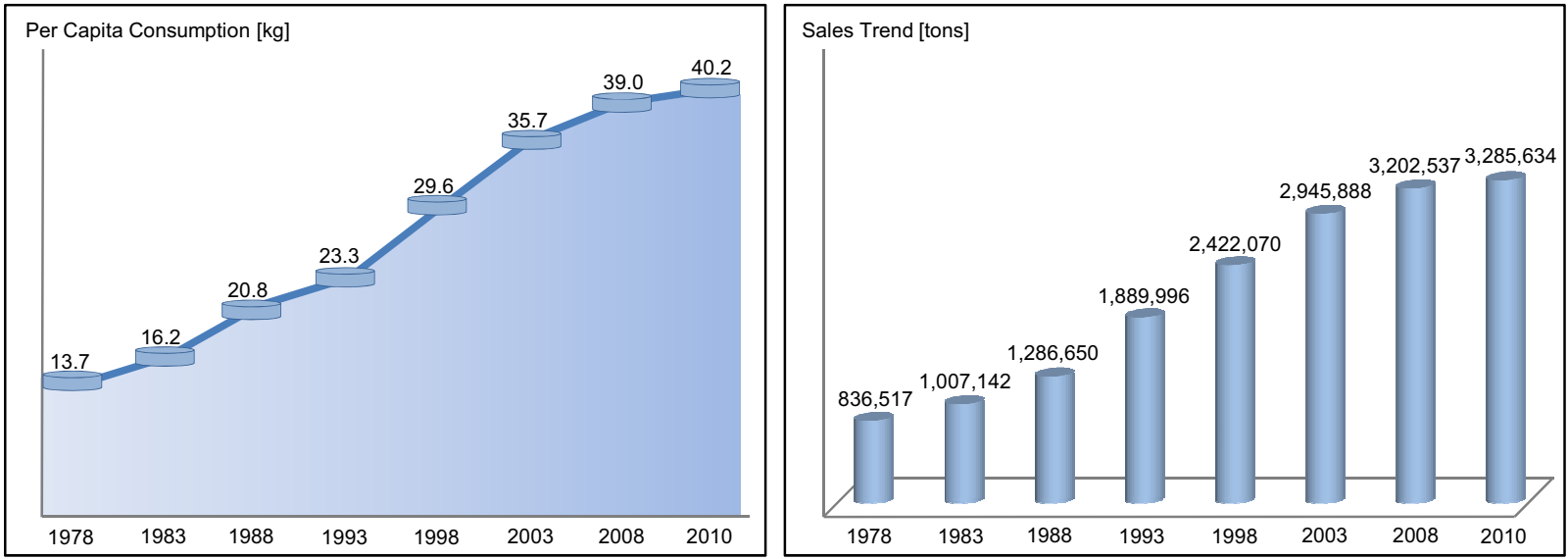

Fig. 1. Per Capita Consumption in kg (left part) and Sales Trend in tons (right part) of frozen food (without ice cream) in Germany from 1978 to 2010 (Source: Deutsches Tiefkühlinstitut e.V., 2011)

\section{Methods}

To comply with absolutely real working conditions, 30 female subjects (Ss) of two age groups (15 females, each, between $20-35$ and 40-65 years) were asked to carry out whole working day tasks in a coldstorage depot with a chill room (at approximately $+3^{\circ}$ ) and a cold store (at approximately $-24^{\circ} \mathrm{C}$ ). The layout of a typical cold-storage depot is described in detail in [21]. The left part of Figure 2 shows the test layout which was developed to enable the measurement of the physical strain while working in an extreme cold environment. The independent variables were the number and duration of cold-exposure per work shift $(80,100,120$ minutes), the length of the warming-up breaks (20 minutes, each, at about $+21^{\circ} \mathrm{C}$ ) as well as a work load of order-picking adapted to the real job of an average of 1.6 tons of goods per hour. Prior to each cold exposure the physical and mental conditions of the participants were registered (cp. Table 1) and a standard $\mathrm{PWC}_{130}$ test (cp. [12]) was carried out in order to determine all individuals' physical capacity of the cardiovascu- lar system in the sub-maximal area. For details about the execution of the $\mathrm{PWC}_{130}$ test see Penzkofer et al. (cp. [20,21]). Afterwards, the Ss were "instrumented" with the measurement systems shown in the right part of Figure 2. Utilizing these devices, the relevant physiological parameters "heart rate" and "skin surface temperature" were measured continuously, and, every $15 \mathrm{~min}$ "body core temperature" and "blood pressure" were recorded discretely. The results of the physiological parameters "body core" and "skin surface temperature" are presented in Baldus et al. [2].

To identify the intensity of the physical work, the energy expenditure was quantified through a mobile spirometry system. The use of the utilized measurement system is described in detail in [19]. Besides the objectively recorded physiological parameters, the subjectively experienced stress and strain was determined via a systematic inquiry. The physiological responses of the cardiovascular system to working in deep cold will be presented in this paper. 
To enable working continuously in the chill room at about $+3{ }^{\circ} \mathrm{C}$ and in the cold store at about $-24^{\circ} \mathrm{C}$, the employees were required to wear cold-protective clothing. In the chill room warm underwear, a thermo shirt, a cold-protective vest, a pair of trousers, a wool hat, knitted gloves and thermo-insulated safety shoes were used. The gloves worn were primarily provided for occupational safety reasons rather than for keep-

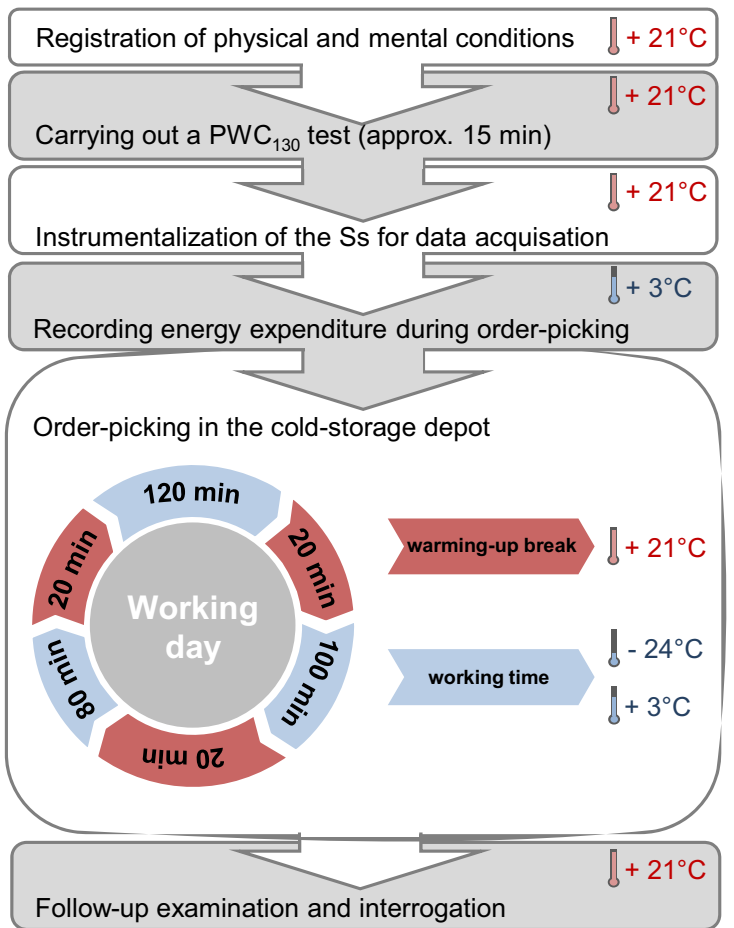

ing the hands warm. In the cold store the same underwear was used, but additionally a pullover, a pair of trousers and, more importantly, a special coldprotective suit were worn. This suit consisted of a thick jacket and long trousers. Furthermore, a thick wool hat, thermo socks, special thermo gloves normally made of fleece - and cold-insulating boots were worn.

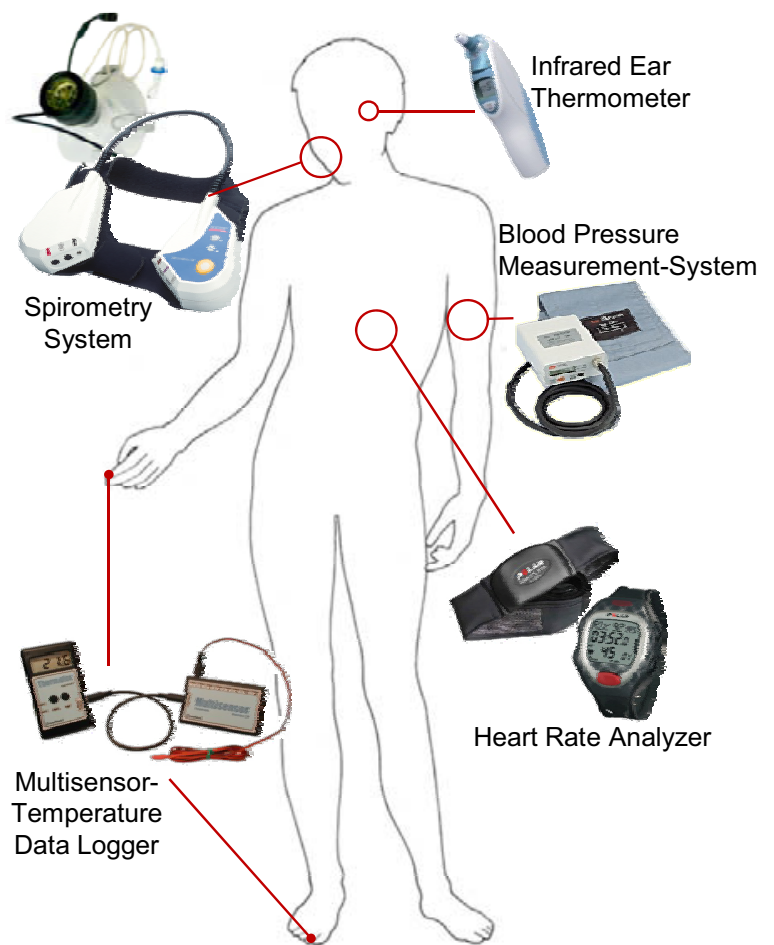

Fig. 2. Diagram of the test procedure (left part) and the measurement equipment for the determination of stress and strain of the Ss in the cold store at $-24^{\circ} \mathrm{C}$ and in the chill room at $+3^{\circ} \mathrm{C}$ (right part).

Table 1

Characteristics of 15 female subjects, each, in the age group "young" (left part) and "old" (right part)

\begin{tabular}{|c|c|c|c|c|c|c|c|c|c|c|c|}
\hline $\begin{array}{l}\text { Ss } \\
\text { young }\end{array}$ & $\begin{array}{l}\text { Age } \\
\text { [Years] }\end{array}$ & $\begin{array}{l}\text { Size } \\
{[\mathrm{m}]} \\
\end{array}$ & $\begin{array}{l}\text { Weight } \\
{[\mathrm{kg}]}\end{array}$ & BMI & $\begin{array}{l}\mathrm{rPWC}_{130} \\
{[\mathrm{~W} / \mathrm{kg}]}\end{array}$ & $\begin{array}{l}\text { Ss } \\
\text { old } \\
\end{array}$ & $\begin{array}{l}\text { Age } \\
\text { [Years] }\end{array}$ & $\begin{array}{l}\text { Size } \\
{[\mathrm{m}]} \\
\end{array}$ & $\begin{array}{l}\text { Weight } \\
{[\mathrm{kg}]}\end{array}$ & BMI & $\begin{array}{l}\mathrm{rPWC}_{130} \\
{[\mathrm{~W} / \mathrm{kg}]}\end{array}$ \\
\hline 01 & 27 & 1.74 & 73 & 24.1 & 1,70 & 01 & 59 & 1.69 & 80 & 28.0 & 1.60 \\
\hline 02 & 24 & 1.76 & 68 & 22.0 & 1.10 & 02 & 54 & 1.63 & 52 & 19.6 & 1.40 \\
\hline 03 & 25 & 1.67 & 67 & 24.0 & 0.70 & 03 & 61 & 1.68 & 61 & 21.6 & 2.00 \\
\hline 04 & 22 & 1.76 & 64 & 20.7 & 1.60 & 04 & 52 & 1.56 & 57 & 23.4 & 1.80 \\
\hline 05 & 20 & 1.62 & 54 & 20.6 & 1.40 & 05 & 53 & 1.70 & 61 & 21.1 & 1.60 \\
\hline 06 & 20 & 1.70 & 77 & 26.6 & 1.00 & 06 & 59 & 1.61 & 53 & 20.4 & 2.40 \\
\hline 07 & 20 & 1.70 & 65 & 22.5 & 1.20 & 07 & 57 & 1.70 & 71 & 24.6 & 1.40 \\
\hline 08 & 21 & 1.80 & 66 & 20.4 & 1.50 & 08 & 43 & 1.58 & 73 & 29.3 & 1.40 \\
\hline 09 & 22 & 1.60 & 59 & 23.0 & 1.70 & 09 & 44 & 1.66 & 67 & 24.3 & 2.20 \\
\hline 10 & 25 & 1.70 & 58 & 21.1 & 1.30 & 10 & 51 & 1.68 & 60 & 21.3 & 1.70 \\
\hline 11 & 28 & 1.63 & 50 & 18.8 & 1.50 & 11 & 44 & 1.76 & 77 & 24.9 & 1.83 \\
\hline 12 & 27 & 1.69 & 59 & 20.7 & 1.30 & 12 & 50 & 1.64 & 60 & 22.3 & 1.70 \\
\hline 13 & 21 & 1.58 & 51 & 20.4 & 1.00 & 13 & 64 & 1.73 & 104 & 34.7 & 1.40 \\
\hline 14 & 32 & 1.71 & 77 & 26.3 & 1.30 & 14 & 61 & 1.73 & 103 & 34.4 & 1.20 \\
\hline 15 & 26 & 1.58 & 71 & 28.4 & 1.80 & 15 & 48 & 1.68 & 55 & 19.5 & 2.30 \\
\hline$\overline{\mathbf{x}} \pm \mathbf{S}_{\mathbf{d}}$ & 24.0 & 1.68 & 63.9 & 23.24 & 1.34 & $\overline{\mathbf{x}} \pm \mathbf{S}_{\mathbf{d}}$ & 53.3 & 1.67 & 68.9 & 24.6 & 1.73 \\
\hline & \pm 3.6 & \pm 0.1 & \pm 8.7 & \pm 4.1 & $\pm \mathbf{0 . 3}$ & & \pm 6.7 & $\pm \mathbf{0 . 1}$ & \pm 16.4 & \pm 4.9 & \pm 0.4 \\
\hline
\end{tabular}




\section{Results}

Work-related heart rate responses (work pulses) indicate physical whole body strain and, therefore, are one of the most important parameters (cp. [2]) when analyzing the effects of working in the cold. Figure 3 shows the heart rate profile above the resting level with 5-min-mean values for working in the chill room (upper part) and cold store (lower part). The individual resting level was identified through 2min-mean values of heart rate throughout the entire working day with a minimum detected and monitored mostly in a sedentary position in the morning when registering the physical and mental conditions, in the evening during the follow-up examination as well as in one of the warming-up breaks.

The heart rate values indicate a high physical strain for the Ss of both age groups. However, in contrast to the expectations, the younger female Ss (grey columns) show significantly higher values than the older Ss (white colums), especially when working in the cold store. The average values of the heart rate above the resting level during the phases of work was $41 \mathrm{bpm}$ for the 20- to 35-year-olds and $33 \mathrm{bpm}$ for the 40- to 65-year-olds when working in the cold store. This may be caused by the lower physical capacity of the younger Ss, determined via the $\mathrm{PWC}_{130}$ test (cp. Table 1). Also the data about weekly sporting activities indicated that the younger Ss exercise sports approx. 0.5 hours less per week than the older ones. Issues of daily life can be another reason for this result since the younger females were mainly students with no additional physical regular work and with no or only small household activities, but the older females had to meet the approval of a family household. Individual peaks of the work pulses up to $78 \mathrm{bpm}$ in the maximum for the younger Ss were partly reached, in the case of the older Ss $54 \mathrm{bpm}$ represented the maximum.
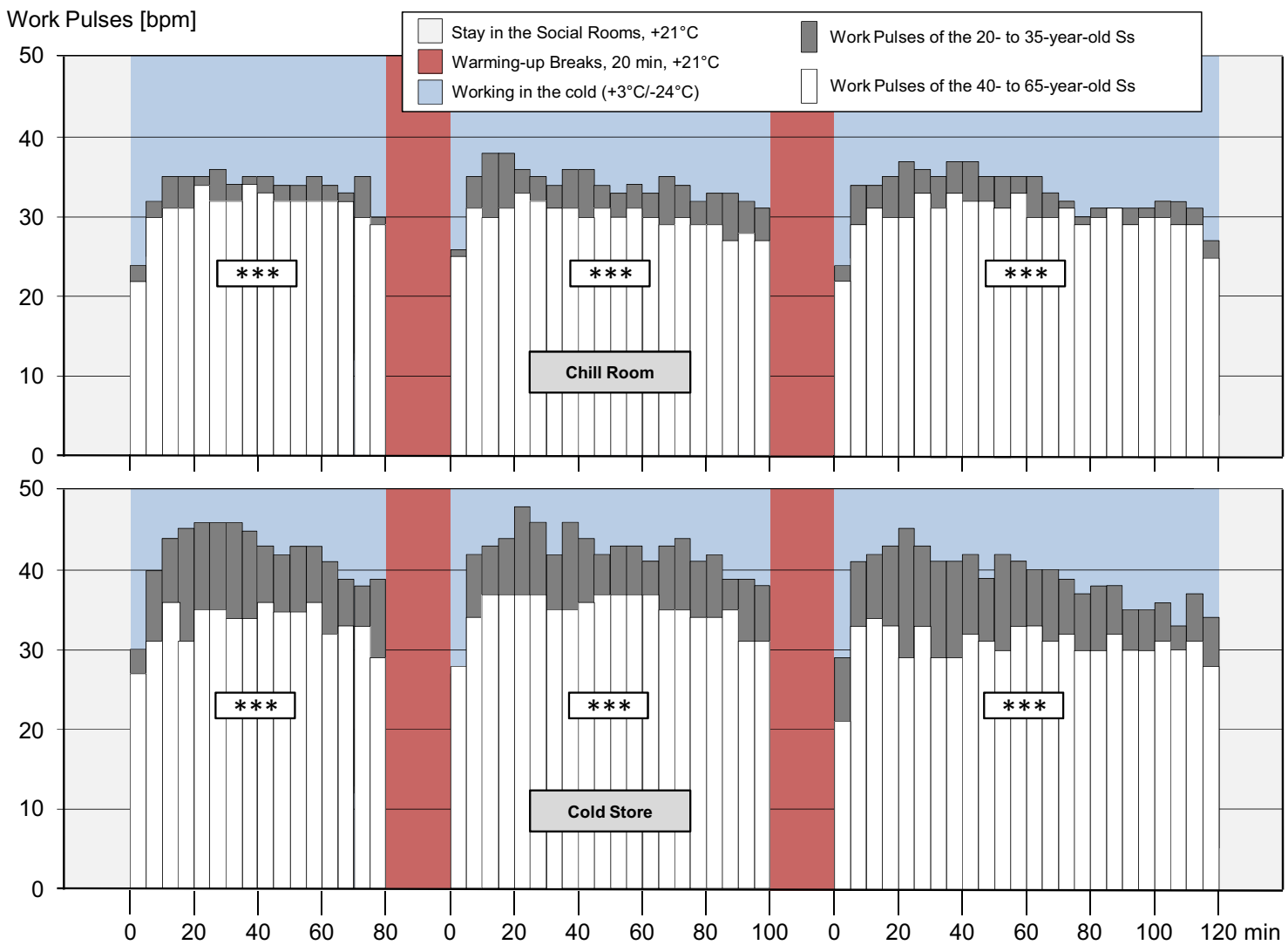

Fig. 3. "Work Pulse"-time diagram averaged over 15 female Ss, each, at the age of 20 to 35 years (height of grey columns) and 40 to 65 years (height of white columns). 5-min values during three working periods over 80, 100 and 120 min in the chill room at $+3^{\circ} \mathrm{C}$ (upper part) and during the same three working periods in the cold store at $-24^{\circ} \mathrm{C}$ (lower part). Symbolic labeling of statistically significant differences of the two-sided t-test (-: $\mathrm{p} \geq 0.05, *: \mathrm{p}<0.05, * *: \mathrm{p}<0.01, * * *: \mathrm{p}<0.001)$. 
When comparing the results from the two cold exposures, the light blue columns in the upper part of Figure 4 (younger Ss) exhibit a substantially and highly significant lower level of work pulses for the cold exposure in the chill room. Carrying out the same work, with regard to the extent of physical load handled in the same course of time, led - in every working phase - to lower values which, on average, amounted to just $33 \mathrm{bpm}$ above the resting level and, therefore, $8 \mathrm{bpm}$ under the work pulses in the cold store. This maybe due to the less heavy protective clothing (with a total weight of $2 \mathrm{~kg}$ in the chill room and $5 \mathrm{~kg}$ in the cold store) and, primarily it may be caused by the lower cold stress. In individual cases, heart rates of approximately $20-25 \mathrm{bpm}$ below the work pulses associated with working in the cold store were measured in the chill room.

The results for the 40- to 65-year-olds (cp. lower part of Figure 4) indicate average work pulses of 30 bpm in the chill room and $33 \mathrm{bpm}$ in the cold store. Slightly smaller differences were measured in each of the three working phases, which where, nevertheless, highly significant in the 80 and 100 minute work phases. No significant differences were registered during continuous working over the period of 120 min. A dotted line marks the work pulses in the cold store in the case where it is even lower than in the chill room.
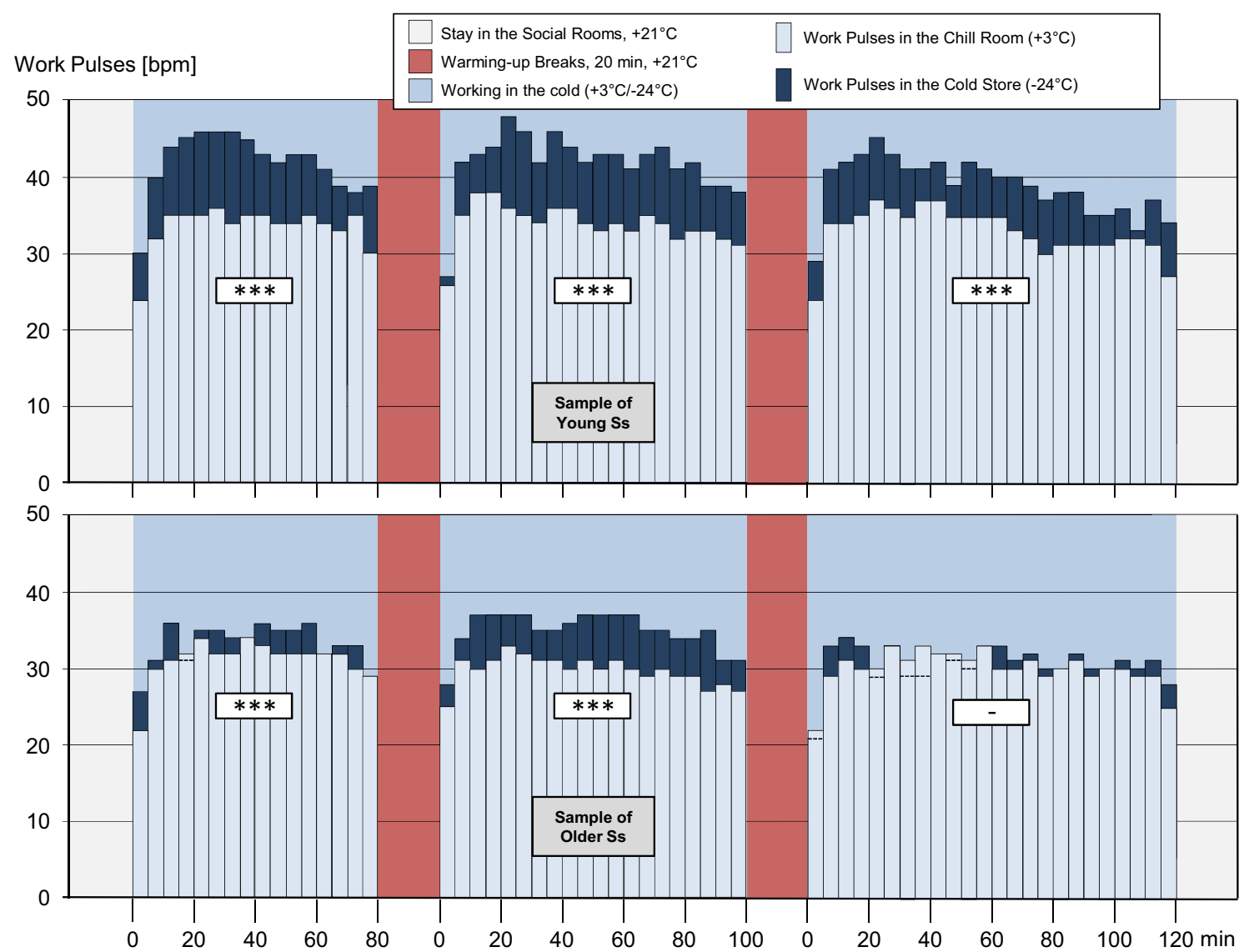

Fig. 4. "Work Pulse"-time diagram averaged over 15 female Ss, each, at the age of 20 to 35 years (upper part) and 40 to 65 years (lower part). 5 -min values during three working periods over 80,100 and $120 \mathrm{~min}$ in the cold store at $-24^{\circ} \mathrm{C}$ (height of dark blue columns behind light blue columns) and during the same three working periods in the chill room at $+3{ }^{\circ} \mathrm{C}$ (height of light blue columns). Symbolic labeling of statistically significant differences of the two-sided t-test $(-: \mathrm{p} \geq 0.05, *: \mathrm{p}<0.05, * *: \mathrm{p}<0.01, * * *: \mathrm{p}<0.001)$. Hidden grey columns are marked through a dotted line. 


\section{Discussion}

Contributions to heart rate increases as physiological responses to working in the cold may be expected due to specifically physiological mechanisms, the cold protective clothing and individual characteristics of the employees who work in the cold.

The physiological mechanisms mainly consist of a useful vasoconstriction in the body's periphery (in order to reduce the temperature gradient to the environment and, thereby, to minimize heat loss), and a hypothetically expected specific blood-pressure increasing effect which may also contribute to heart rate increases.

The cold protective clothing, on the one hand, reduces thermoregulatory responses to the cold as it covers almost all body areas, but on the other hand the weight of the protective clothing can also have an impact on activation of the cardiovascular system. Prior research, carried out by Hertting et al. (cp. [11]) showed that heavy heat protection clothing (e.g. a flame-retarding smelter suit with an aluminium backed smelter coat), with a total weight between 5 and $6 \mathrm{~kg}$ has a clear effect on work-related heart rates. Increases of approximately $10 \mathrm{bpm}$ due to the weight of the clothing alone have been recorded. Penzkofer et al. [21] registered 5-10 bpm higher heart rates for male order-pickers when working in the cold store compared to the chill room. When comparing the results from Hertting et al. and Penzkofer et al. with the findings of this study, where work-related heart rates were about $8 \mathrm{bpm}$ higher when working in the cold store, it can be assumed that the cold protective clothing alone, with a total weight of approximately 5 $\mathrm{kg}$, caused the increased heart rate.

Individual characteristics of the Ss also influenced the heart rate to a great extent when working in the cold. The originally expected substantial differences between the two experimental groups, with higher values for the older Ss due to an age-related lowered physical capacity, did not occur. Therefore, factors like the heart rate capacity and the individual fitness must be considered.
The utilization of heart rate increases is reduced with advancing age due to the fact that, for every human, the maximum heart rate is lowered per year of life according to the following formula: $\mathrm{HR}_{\max }=$ 208 - (0.7 x age) (cp. [24,27]). When considering a resting level of the older Ss which is on average 10 bpm lower than the resting level of the younger Ss, the capacity utilization is on average approx. 39\% (chill room) and $41 \%$ (cold store) for both age groups. In this case a work pulse profile with nearly identical increases above the resting level would mean slightly higher capacity utilization for the older Ss, but a higher work pulse profile for the older Ss is more problematic.

Figure 5 visualizes the average heart rate profile of the 120 min working phase for both age groups in the chill room and the cold store. When considering a maximum heart rate of $191 \mathrm{bpm}$ for the younger Ss (left part of Figure 5) and an average heart rate of 108 bpm in the chill room and $118 \mathrm{bpm}$ in the cold store, the average capacity utilization $\left(\mathrm{HR} / \mathrm{HR}_{\max }\right)$ is $57 \%$ and $62 \%$, respectively.

The maximum heart rate for the older Ss (right part of Figure 5) is $171 \mathrm{bpm}$, therefore, with heart rates of $96 \mathrm{bpm}$ in the chill room and $100 \mathrm{bpm}$ in the cold store, the average capacity utilization is $56 \%$ and $59 \%$, respectively. The example shown is representative for all working phases as the capacity utilization was nearly identical when working in the chill room and slightly higher for the younger Ss when working in the cold store. The average capacity utilization of all 3 working phases in the chill room and in the cold store was $57 \%$ and $63 \%$, respectively, for the younger Ss and $57 \%$ respectively $60 \%$ for the older Ss.

Another reason for the higher heart rates of the younger Ss might be the already mentioned lower relative physical capacity, less sporting activities and a less physically challenging daily life.

The study results show that order-picking in deep cold leads to high physical stress for women of both age groups. Nevertheless, order-picking work itself is - due to the heat production - beneficial rather than an additional stress as long as the work takes place within the order-pickers physiological performance capacity and thus within the endurance limit. 


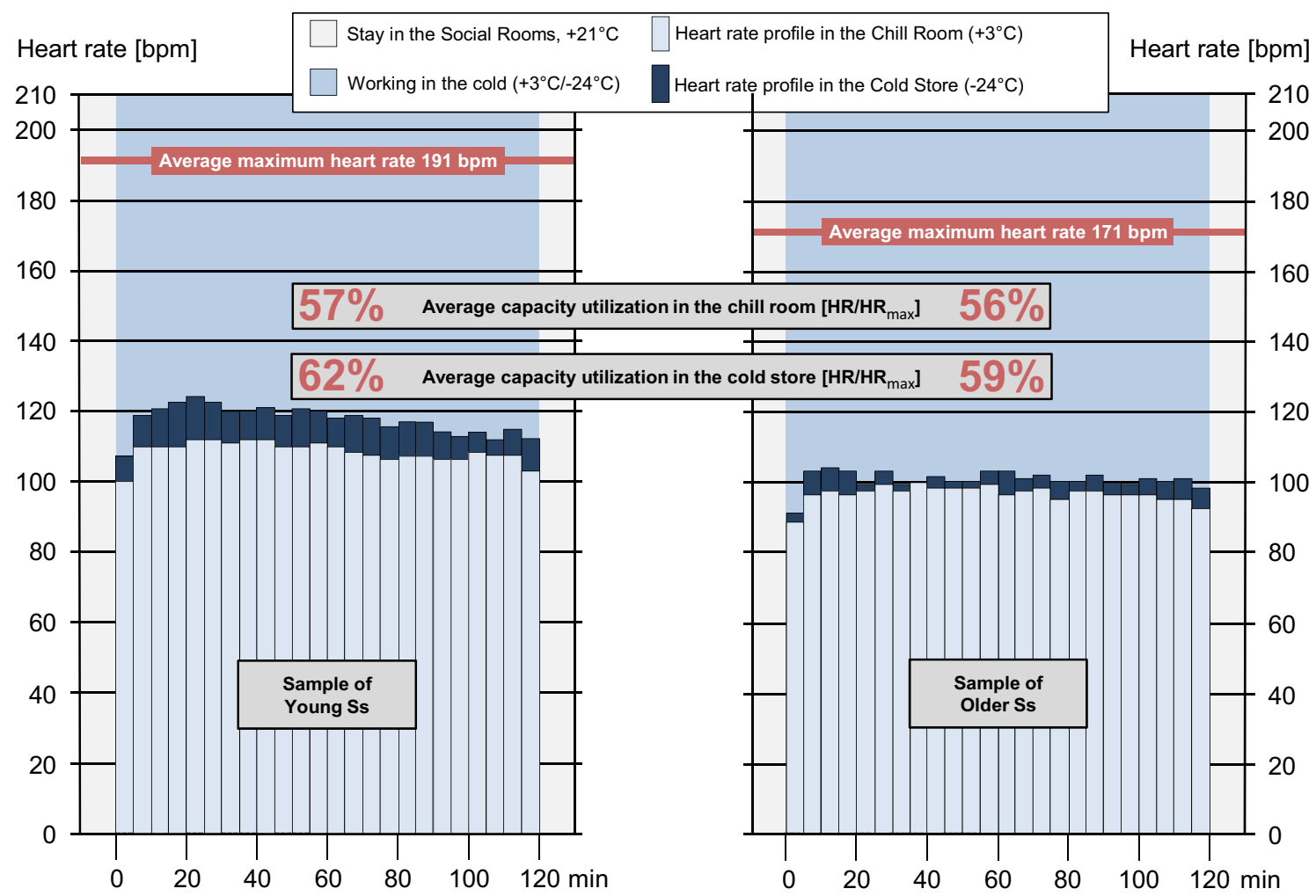

Fig. 5. Heart rate-time diagram averaged over 15 female Ss, each, at the age of 20 to 35 years (left part) and 40 to 65 years (right part). 5-min values during the 120 min working phase in the cold store at $-24^{\circ} \mathrm{C}$ (height of dark blue columns behind light blue columns) and during the same working period in the chill room at $+3^{\circ} \mathrm{C}$ (height of light blue columns).

\section{Conclusion}

According to prognoses on a national and international level, the demographic development and the resulting changes in society will lead to a clear increase of the age of the workforce, although even more females will be present in almost all jobs. This means that the topic discussed here remains highly relevant because the physical capacity and muscular strength decreases with an advanced age and is less for women than for men. When comparing the results of this study with the findings of Penzkofer et al. [20$21]$, for the young females significantly higher heart rates have been measured than for the young males ( 6 and $8 \mathrm{bpm}$ for the chill room and the cold store, respectively). Therefore, a gender difference is clearly visible in this case. However, in contrast to the expectations, the heart rate values of the older women were slightly lower when working in the chill room and significantly lower when working in the cold store compared to older male workers. Older females even showed the same heart rate values as young males did when working in the cold store.
The results support the suggestion that older people are not necessarily less efficient than younger ones. The same is true when comparing males and females, even if the latter are at a clear disadvantage through their physiological conditions. Humans' health ultimately depends on the work organisation during the whole working live. Therefore, companies are to a certain extent also responsible for their workers' ability to work and their employability, such as working at extremely low temperatures. In this context, occupational health and safety for younger and older employees plays an important role because health problems have a decisive impact on the efficiency of the workforce and normally evolve slowly over many years. Decisive causes are, among other things, the working environment, such as extreme climatic conditions at work. In order to make "working at very low temperatures" more compatible to an aging workforce in the long run, more attention has to be paid to the combined parameters of age, gender and cold with special regard to the individuals' physical capacity. 


\section{References}

[1] E.P. Adolph. and G.W. Molnar, Exchanges in heat and tolerances to cold in men exposed to outdoor weather, American Journal of Physiology, 146 (1946), 507-537.

[2] S. Baldus, K. Kluth and H. Strasser, Order-picking in deep cold - physiological responses of younger and older females. Part 2: body core temperature and skin surface temperature, in: Proceedings of the $18^{\text {th }}$ World Congress on Ergonomics, Recife, Brazil, 2012

[3] W.M. Boothby, J. Berkson and H.L. Dunn, Studies of the energy metabolism of normal individuals, a standard for basa metabolism, with a nomogram for clinical application, American Journal of Physiology 116(2) (1936), 468-484

[4] G.M. Budd and N. Warhaft, Body temperature, shivering, blood pressure and heart rate during standard cold stress in Australia and Antarctica, Journal of Physiology, 186 (1966), 216-232.

[5] A. Forsthoff, Arbeit in $-28^{\circ} \mathrm{C}$, Arbeitsphysiologische Untersuchung zur klimatischen Belastung bei Körperarbeit in extrem tiefen Umgebungstemperaturen unter besonderer Berücksichtigung der Kühlhausarbeit, Dokumentation Arbeitswissenschaft, Band 9, 1983

[6] B. Griefahn, Arbeit in mäßiger Kälte, Schriftenreihe der Bundesanstalt für Arbeitsschutz, Forschung, Fb 716, Wirtschaftsverlag NW, Bremerhaven, 1995.

[7] H. Häcker, Psychologische Determinanten von Kältearbeit bei $-30^{\circ} \mathrm{C}$, Schriftenreihe der Bundesanstalt für Arbeitsschutz, Forschung, Wirtschaftsverlag NW, Dortmund, 1989

[8] J. Hassi, T. Mäkinen, I. Holmér, A. Påsche and T. Risikko, Handbok für kallt arbete, Arbetslivsinstitutet, Solna, 2002.

[9] J. Hassi, M. Rytkönen, J. Kotaniemi and H. Rintamäki, Impacts of cold climate on human heat balance, performance and health in circumpolar areas, International Journal of Circumpolar Health, 64(5) (2005), 459-467.

[10]B. Hellstrøm, K. Berg and F. Vogt Lorentzen, Human peripheral warming during exercise in cold, Journal of Applied Physiology, 29 (1970), 191-199.

[11]R. Hertting, T. Hettinger and G. Eissing, Einfluss von Schutzkleidung auf die Beanspruchung des Menschen bei Arbeit unter Wärmestrahlungsexposition, Arbeitsmedizin - Sozialmedizin - Präventivmedizin, 19(1) (1984), 9-14.

[12]HVBG, Leitfaden für die Ergometrie bei Arbeitsmedizinischen Vorsorgeuntersuchungen nach berufsgenossenschaftlichen Grundsätzen (Anhang 2), in: Berufsgenossenschaftliche Grundsätze für arbeitsmedizinische Vorsorgeuntersuchungen, Gentner Verlag, Stuttgart, 2002.

[13]R. Kleinöder, Ergonomische Gestaltung von Kältearbeit bei $30^{\circ} \mathrm{C}$ in Kühl- und Gefrierhäusern, Schriftenreihe der Bundesanstalt für Arbeitsschutz, Forschung, Wirtschaftsverlag NW, Dortmund, 1988

[14]K. Kluth, M. Penzkofer and H. Strasser, Age-related analysis and assessment of the effects of working in the cold on skin temperature and core temperature of male order-pickers, in: Proceedings of the $2^{\text {nd }}$ International Conference on Applied Human Factors and Ergonomics, Las Vegas, Nevada, USA 2008 .

[15]K. Kluth, M. Penzkofer and H. Strasser, Physiological responses of core and skin temperature of two age groups to working in the cold at $+3{ }^{\circ} \mathrm{C}$ and $-24^{\circ} \mathrm{C}$, Occupational Ergonomics 8(4) (2008/2009), 147-157.

[16]T.M. Mäkinen, Human cold exposure, adaptation, and performance in high latitude environments, American Journal of Human Biology, 19(2) (2007), 155-164.
[17]J. Oksa, M.B. Ducharme and H. Rintamäki, Combined effect of repetitive work and cold on muscle function and fatigue, Journal of Applied Physiology, 92(1) (2002), 354-361.

[18]H. Ozaki, H. Enomoto-Koshimizu, Y. Tochihara and K. Nakamura, Thermal responses from repeated exposure to severe cold with intermittent warmer temperatures, 17(5) (1998), 195-205.

[19]M. Penzkofer, K. Kluth and H. Strasser, Feasibility-Study zur altersdifferenzierten Beurteilung von TiefkühlhausKommissionierarbeit, in: Gesellschaft für Arbeitswissenschaft, ed., Kompetenzentwicklung in realen und virtuellen Arbeitssystemen, GfA Press, Dortmund, 2007, 767-770.

[20]M. Penzkofer, K. Kluth and H. Strasser, Physiological responses of male subjects to cold exposure at $+3^{\circ} \mathrm{C}$ and $-24^{\circ} \mathrm{C}$ during warehouse commissioning work, in: Proceedings of the $2^{\text {nd }}$ International Conference on Applied Human Factors and Ergonomics, Las Vegas, Nevada, USA, 2008.

[21]M. Penzkofer, K. Kluth and H. Strasser, Heart rate and work pulses of two age groups associated with working in the cold at $+3^{\circ} \mathrm{C}$ and $-24^{\circ} \mathrm{C}$, Occupational Ergonomics 8(4) (2008/2009), 135-145.

[22]E. Sormunen, J. Oksa, T. Pienimäki, S. Rissanen and H. Rintamäki, Muscular and cold strain of female workers in meatpacking work, International Journal of Industrial Ergonomics, 36(8) (2006), 713-720.

[23]H. Strasser and K. Kluth, Sensations of cold and physiological responses to groceries handling in cold-storage depots, in: Proceedings of the $16^{\text {th }}$ Triennial Congress of the International Ergonomics Association, 6 pp., Maastricht, The Netherlands, 2006

[24]H. Tanaka, K. Monahan and D. Seals, Age-predicted maximal heart rate revisited, Journal of the American College of Cardiology, 37 (2001), 153-159.

[25]Y. Tochihara, Work in artificial cold environments, Journal of Physiological Anthropology and Applied Human Science 24(1) (2005), 73-76.

[26]Y. Toshihara, C. Ohkubo, I. Uchiyama and H. Komine, Physiological reaction and manual performance during work in cold storages, Applied Human Science 14(2) (1995), 73-77.

[27] M. Whaley, L. Kaminsky, G. Dwyer, L. Getchell and J. Norton, Predictors of over- and under-achievement of agepredicted maximal heart rate, Medicine \& Science in Sports \& Exercise, 24 (1992), 1173-1182. 